\title{
Does the transplantation of keratinocytes really reduce the risk of death? Survival analysis of patients hospitalized at the Dr Stanisław Sakiel Centre for Burns Treatment in 2008-2015
}

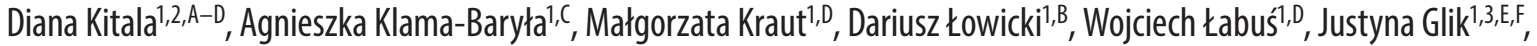 \\ Marcelina Misiuga ${ }^{1,4, B, D}$, Mariusz Nowak ${ }^{1, E, F}$, Grażyna Lisowska ${ }^{5, F}$, Raphael Olszewski ${ }^{6, E}$, Marek Kawecki ${ }^{1,7, A, E, F}$ \\ ${ }^{1}$ Dr Stanisław Sakiel Centre for Burns Treatment, Siemianowice Śląskie, Poland \\ ${ }^{2}$ Silesian Higher Medical School, Katowice, Poland \\ ${ }^{3}$ Department of Chronic Wounds Management Organization, School of Health Sciences, Medical University of Silesia, Katowice, Poland \\ ${ }^{4}$ Silesian Analytical Laboratories, Katowice, Poland \\ ${ }^{5}$ Department and Clinical Ward of Otolaryngology and Laryngological Oncology, School of Medicine with the Division of Dentistry, Medical University of Silesia, Zabrze, Poland \\ ${ }^{6}$ Department of Oral and Maxillofacial Surgery, University Hospital St. Luc, Catholic University of Leuven, Brussels, Belgium \\ ${ }^{7}$ Department of Emergency Medicine, School of Health Sciences, University of Bielsko-Biala, Poland \\ A - research concept and design; $\mathrm{B}$ - collection and/or assembly of data; $\mathrm{C}$ - data analysis and interpretation; \\ $D$ - writing the article; $E$ - critical revision of the article; $F$ - final approval of the article
}

Address for correspondence

Marcelina Misiuga

E-mail:m_piskorz@vp.pl

Funding sources

None declared

Conflict of interest

None declared

Received on February 1, 2017

Reviewed on March 22, 2017

Accepted on August 7, 2017

Published online on November 23, 2018

Cite as

Kitala D, Klama-Baryła A, Kraut M, et al. Does the transplantation of keratinocytes really reduce the risk of death? Survival analysis of patients hospitalized at the Dr Stanisław Sakiel Centre for Burns Treatment in 2008-2015. Adv Clin Exp Med. 2019;28(1):5-10. doi:10.17219/acem/76327

DOI

10.17219/acem/76327

Copyright

Copyright by Author(s)

This is an article distributed under the terms of the

Creative Commons Attribution Non-Commercial License

(http://creativecommons.org/licenses/by-nc-nd/4.0/)

\section{Abstract}

Background. Keratinocyte transplantation is an adjuvant procedure in the extensive burn therapy method. However, it must be taken into consideration that clinical results of keratinocyte transplantation are ambiguous and progress achieved in this method is still being verified, especially due to the high cost of cultured epithelial autograft (CEA) transplants.

Objectives. The aim of this study was to verify the impact of cultured keratinocyte application on patients' survival. This study included a group of patients with the highest chance for a successful outcome of the therapy and excluded patients with no compelling reason to apply for such an expensive therapy.

Material and methods. This study included all the patients with burns diagnosed between January 1, 2008 and January 1, 2016, who were treated with cultured skin cells. Patients' age and gender, percentage of total body surface area (TBSA) affected, percentage of burn depth of the $3^{\text {rd }} / 4^{\text {th }}$ degree, number of days between admission and surgery, and need for rehabilitation were analyzed.

Results. The cultured cell application did not significantly affect the risk of death $(p>0.05)$

Conclusions. Keratinocytes should be applied as an adjunctive method for the treatment of burns with at least 40\% TBSA affected, but with a maximal burn depth of the $2^{\text {nd }}$ degree. In the group of patients below 50 years of age, a higher number of transplants with a cell population above 20 million/mL and a significantly lower mortality rate were observed, which means that in the mentioned age group, this graft was more effective. It has been suggested that patients older than 50 years of age with burns deeper than of the $2^{\text {nd }}$ degree should be treated with more advanced methods like, e.g., the application of stem cells.

Key words: burn, keratinocytes, advanced therapy medicinal product, cell graft 


\section{Introduction}

During the last decades, the methods of managing burns have changed. ${ }^{1-3}$ The early excision of necrotic tissue and wound closure with autologous, split-thickness skin graft (STSG) are now the basis of treatment. ${ }^{4-6}$ In the case of extensive burns, donor site access is limited. Keratinocyte transplantation is an adjuvant procedure in the extensive burn therapy method. ${ }^{1}$ Using cellular epithelial autografts (CEA) in burns treatment has recently also become more popular. ${ }^{7}$ This technique provides the ability to obtain a high volume of cultured epithelial cells from a skin punch biopsy within $3-4$ weeks. ${ }^{8}$ Cell transplantation increases wound healing by providing 1-stage coverage of extensive skin loss, thereby reducing the number of necessary surgeries. ${ }^{7}$ However, it must be taken into consideration that clinical results of keratinocyte transplantation are ambiguous and progress achieved since Rheinwald and Green's era, when they described keratinocyte culture technique for the first time, is still being verified, especially due to the high cost of CEA transplants. ${ }^{1,9}$ It has been proven, for instance, that a positive result of this therapy is related to the cell donor's age. ${ }^{10}$ Among other limitations of this method, there is the long waiting time for cultured skin components, as well as the susceptibility of the cell culture to infections. ${ }^{11}$ The discrepancy between the observed therapeutic effects is puzzling. Still et al. suggested that keratinocyte application gave a disappointing clinical effect. ${ }^{12}$ Desai et al. observed hyperkeratosis and formation of scar contractures as an after-effect of the cellular therapy. ${ }^{13}$

The aim of this study was to verify the impact of cultured keratinocyte application on patients' survival, based on an analysis of a group of burn patients with cell transplants, in relation to the mean number of deaths among all patients and to the selection of predictive factors related to the risk of death in patients treated with CEA. This study would then allow us to select a group of patients with the highest chance for a successful outcome of the therapy and to exclude patients who do not have a compelling reason to apply for such an expensive therapy.

\section{Material and methods}

\section{Cell culture}

Keratinocytes and fibroblasts were collected from living donors who signed informed consent forms for autologous skin transplantation. A small skin fragment was collected under operating theater conditions. Then, in aseptic rooms with laminar flow cabinets, cells were isolated in accordance with Good Manufacturing Practice (GMP) standards (our laboratory has the manufacturing approval issued by GMP). Firstly, the epidermis was separated from the dermal layer by using the $2.4 \mathrm{U} / \mathrm{mL}$ disphase enzyme (Corning,
Tewksbury, USA). The incubation in the enzyme lasted about $60 \mathrm{~min}\left(\right.$ at $37^{\circ} \mathrm{C}$ ). Later, singular keratinocytes were digested from the dermis by incubation in an enzymatic solution at $37^{\circ} \mathrm{C}$ for $5 \mathrm{~min}$, using TrypLE (Gibco; Thermo Fisher Scientific, Waltham, USA). The culture medium was used for enzyme inactivation. Then, cell suspension was centrifuged for $10 \mathrm{~min}$ at $1500 \mathrm{rpm}$. A cell pellet was suspended in the keratinocyte growth medium Keratinocyte Serum-Free Growth Medium (KSFM) (Gibco; Thermo Fisher Scientific) and seeded into $75 \mathrm{~cm}^{2}$ culture bottles (Sarstedt AG \& CO, Nümbrecht, Germany). The dermis was placed on a Petri dish (Thermo Fisher Scientific), filled with the TrypLE solution, and then incubated for $10 \mathrm{~min}$. After incubation, the enzyme was inactivated and added to Dulbecco's Modified Eagle Medium (DMEM) (Cytogen, Princeton, USA). Established cultures of skin cells were placed in an incubator at a constant temperature of $37^{\circ} \mathrm{C}$, $5 \%$ concentration of $\mathrm{CO}_{2}$ and $95 \%$ humidity. The cell culture was immersed in the medium, which was changed approx. every $48 \mathrm{~h}$, and the growth of the colony was monitored. After reaching $80 \%$ confluence, the cells were passed using TrypLE. Before the transplantation procedure, the cells were counted and their viability was tested using the Tali ${ }^{\circledR}$ Dead Cell Red Kit on Tali ${ }^{\circledR}$ Image-Based Cytometer (Life Technologies, Carlsbad, USA). The analysis was performed in accordance with the manufacturer's protocol.

\section{Population analysis and data collection}

This study included all the patients with burns diagnosed between January 1, 2008 and January 1, 2016, who were treated with cultured skin cells. The study was carried out at the Dr Stanisław Sakiel Centre for Burns Treatment in Siemianowice Śląskie (Poland). The data of burn patients had been collected until the end of their hospitalization period and stored using the Solmed computer software (SPIN Sp. z o.o., Katowice, Poland), as well as in the Laboratory of in vitro Cell and Tissue Culturing with Tissue Bank, localized at the Dr Stanisław Sakiel Centre for Burns Treatment in Siemianowice Śląskie, Poland. To create and encode the database, we used Microsoft Excel 2007 (Microsoft, Redmond, USA).

\section{Analyzed parameters}

Patients' age and gender, percentage of TBSA affected, percentage of burn depth of the $3^{\text {rd }} / 4^{\text {th }}$ degree, number of days between admission and surgery, and need for rehabilitation were analyzed.

The analysis included 81 patients diagnosed with thermal burns (Table 1) who were treated with autologous skin components. Within this group, $86 \%$ patients were male. The control group included 3,919 patients with thermal burns, hospitalized at the Dr Stanisław Sakiel Centre for Burns Treatment in Siemianowice Śląskie, in the same period. The age of the patients admitted to hospital 
and the patients who underwent cell transplantation was not significantly different; however, there was a difference in their burn surfaces $(p<0.01)$. Most of the patients with cultured cells had burns covering 40-79\% TBSA (59\% of the patients), whereas among the admitted patients, burns with up to $39 \%$ TBSA dominated (75\% of the patients). Patients with cultured cells later underwent a necrotic tissue demarcation procedure, mainly due to the larger size of the burn surface, which required a longer hemodynamic stabilization of those patients.

\section{Statistical analysis}

The STATISTICA v. 12 (StatSoft Inc., Tulsa, USA) program was used. For the analysis of variances, Cox's proportional hazard models were constructed. The model assumptions were checked by the Schoenfeld residuals analysis. If the assumption of proportional hazard was not fulfilled, the variance proved to be linearly time-dependent. The goodness of fit was evaluated by Akaike's Information Criterion (AIC). The model with the best statistical fit was selected (AIC $=65.48$ ). To compare the group of patients who underwent autologous keratinocyte transplantation with the total number of hospitalized patients, the Mann-Whitney U test was used for both groups. The assumption of normal distribution was analyzed by the ShapiroWilk normality test. The $X^{2}$ test was used to compare frequency distribution. The statistical significance obtained was $\alpha=0.05$. Furthermore, the relative risk reduction (RRR) for number of deaths was compared:

$$
R R R=\frac{z_{c}}{n_{c}}-\frac{n_{k}}{z_{k}}
$$

where:

$n_{c}$ - total number of patients in the CEA group;

$n_{k}-$ total number of patients in the control (non-CEA) group;

$z_{e}-$ event rate in the CEA group (number of deaths);

$z_{k}-$ event rate in the control group (number of deaths).

\section{Results}

The analysis showed that the only significant prognostic factor was the burn surface of the $3^{\text {rd }}$ degree at least $(p=0.029)$. Every $10 \%$ increase in the burn surface resulted in increasing the risk of death by $75.2 \%$ (hazard ratio confidence interval (HR CI): $1.06-2.9)$. In the case of burns of the $3^{\text {rd }} / 4^{\text {th }}$ degree, covering more than $40 \%$ TBSA, the probability of a 3-month survival was $60 \%$ (Fig. 1). The cultured cell application did not significantly affect the risk of death ( $p>0.05)$; however, when a selected group of patients was taken into consideration (40-79\% TBSA affected), the relative reduction of death was $69.6 \%$ in the group of patients with CEA transplantation in comparison to the pair-matched group without CEA graft (Table 2).

Table 2. Differences between pair-matched groups with $40-79 \%$ TBSA affected

\begin{tabular}{|c|c|c|}
\hline Grouping descriptive parameters & CEA group & $\begin{array}{l}\text { Non-CEA } \\
\text { group }\end{array}$ \\
\hline $\begin{array}{l}\text { Patients with TBSA affected, n [\%] } \\
40-59 \% \\
60-79 \% \\
\text { total }\end{array}$ & $\begin{array}{c}25(52.08) \\
23(47.92) \\
48\end{array}$ & $\begin{array}{c}25(52.08) \\
23(47.92) \\
48\end{array}$ \\
\hline Age [years] & $38 \pm 13$ & $41 \pm 18$ \\
\hline $\begin{array}{l}\text { Number of days from admission } \\
\text { to main operation, mean } \pm S D\end{array}$ & $38 \pm 21$ & $11 \pm 11$ \\
\hline Hospitalization length [days], mean \pm SD & $82 \pm 44$ & $38 \pm 36$ \\
\hline Number of rehabilitated patients & 13 & 6 \\
\hline Death, n [\%] & $7(14.6)$ & $23(48.0)$ \\
\hline
\end{tabular}

TBSA - total body surface area; SD - standard deviation; CEA - cellular epithelial autografts. 
The application of keratinocyte cells was not a procedure which could eliminate the need for rehabilitation; $73 \%$ of patients who underwent skin cell transplantation needed rehabilitation due to contracture scars. It has to be pointed out, however, that in the group of patients without cell transplantation, rehabilitation was necessary in $86 \%$ of the cases, which represents a significantly higher percentage of patients than in the previous group.

Burn patients were divided into 2 age groups: $\leq 50$ years and $>50$ years, and then they were compared using the following criteria: burn surface, burn depth, number of days between the admission to hospital, time length of the cell culture, and deaths (Table 3). The comparison was performed to verify if the patient's age over 50 years could affect the proliferation of cultured keratinocytes.

The average number of transplanted cells in the $\leq 50$ years group was 7.7 million $/ \mathrm{mL}$ (Fig. 2), and in the $>50$ years group, it was $6.2 \mathrm{million} / \mathrm{mL}(\mathrm{p}>0.05)$. The percentage of persons with a cell transplant higher than 20 million cells $/ \mathrm{mL}$ in the $\leq 50$ years group was $11 \%$; however, in the $>50$ years group, no patients were reported to reach such a high volume of culture (above 20 milion/mL). Additionally, in patients over 50 years of age, the average time

Table 3. Age, burn surface, time length of the cell culture, and deaths in 2 age groups of patients: $\leq 50$ years and $>50$ years

\begin{tabular}{|c|c|c|c|}
\hline Parameter & Age $\leq 50$ years & Age $>50$ years & $\begin{array}{c}\text { Difference } \\
\text { between } \\
\text { the } 2 \text { groups }\end{array}$ \\
\hline Age [years], median \pm SD & $35.2 \pm 9.4$ & $60.6 \pm 8$ & - \\
\hline TBSA affected [\%], median \pm SD & $41.8 \pm 21.6$ & $32.3 \pm 19.1$ & $p=0.01^{*}$ \\
\hline $\begin{array}{l}\text { Percentage of burn of the } 3^{\text {rd }} / 4^{\text {th }} \\
\text { degree, median } \pm S D\end{array}$ & $8 \pm 3.5$ & $7.6 \pm 1.9$ & $p>0.05$ \\
\hline $\begin{array}{l}\text { Time length of cell culture [days], } \\
\text { median } \pm S D\end{array}$ & $35.5 \pm 16.2$ & $44.8 \pm 27.1$ & $p>0.05$ \\
\hline Deaths [\%] & 4 & 9 & $p=0.038^{*}$ \\
\hline
\end{tabular}

SD - standard deviation; TBSA - total body surface area; ${ }^{*}$ burned body surface area. length of the cell culture was 10 days longer. In the group of patients aged $\leq 50$ years, the cultured cells were applied to persons with a higher median of burn surface (42\% TBSA affected) and, despite that, the mortality rate was significantly lower (4\%).

\section{Discussion}

The application of cultured keratinocytes is considered a step forward in the treatment of massive burns. ${ }^{14}$ The transplantation of skin cells is regarded as a procedure which minimizes the number of autologous donor sites and reduces hypertrophic scarring. ${ }^{9}$ Keratinocyte engraftment at the level of $50-90 \%$ is believed to be possible in the case of partial thickness burns. ${ }^{11,15}$ It has to be remembered, however, that in the case of large burn surfaces, a singular transplantation of skin cells is not sufficient, and that single-place multiple harvesting of a skin section for the culturing purpose requires a large surface. ${ }^{16}$ Using allogeneic cell transplants or an autologous cell culture, supported with an allogeneic human skin matrix, can be the solution here. ${ }^{15}$ The latter solution prevents the 'alligator skin effect', which occurs as a result of a meshed autologous skin graft. ${ }^{16}$ It also helps with performing an earlier closure of the burn wound. ${ }^{14}$

The average survival of patients who underwent CEA transplantation, as presented by Sood et al., is $91 \% .{ }^{17}$ Such a result is in line with those presented in our study (88\%). Postoperative complications are divided into both early and late. Early complications include the presence of blisters (31\%) and pruritus (4.7\%). Late complications include cell transplant loss $(2.3 \%)$ and the presence of scar contractures

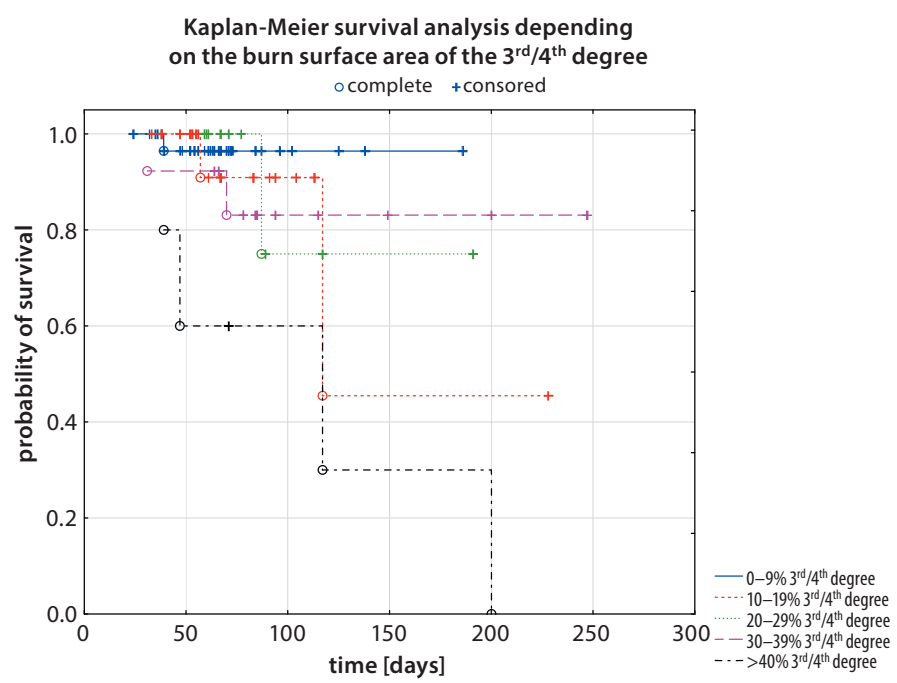

Fig. 1. Probability of survival depending on the burn surface, burns of the $3^{\text {rd }} / 4^{\text {th }}$ degree

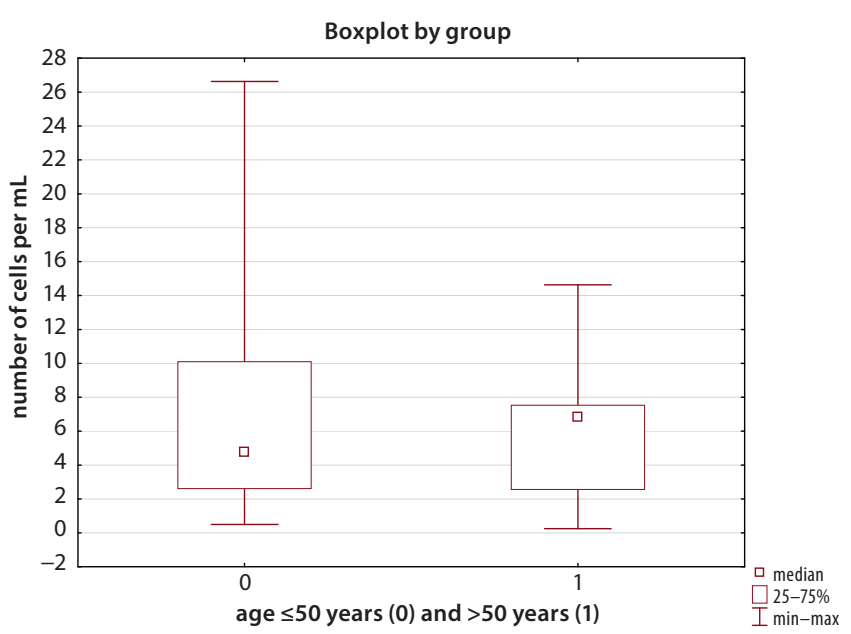

Fig. 2. Number of cells per $\mathrm{mL}$ transplanted in groups of patients aged $\leq 50$ years and $>50$ years 
(66\%). Therefore, it is important that the group of cell transplant recipients should be clearly and precisely defined. The desirability of performing an expensive, timeconsuming and esthetically uncertain procedure is morally and clinically unjustified for groups of patients with spontaneously healed burn wounds ( $2^{\text {nd }}$ degree burns) or in groups of patients with deep $3^{\text {rd }} / 4^{\text {th }}$ degree burns of more than $40 \%$ TBSA affected, in which the probability of 200-day survival is equal to 0 . Carrying out cell cultures for patients with a high risk of death is particularly difficult, because initially, the cell culture is a reflection of the patient's overall condition, which impinges on the epidermal cell viability and population doubling. ${ }^{18}$

The patient's dressing prior to cell collection can also affect the therapeutic success. It has been proven that cultured cells do not reveal the adhesive abilities in the presence of wound dressings such as Adaptic ${ }^{\circledR}$, Xeroform ${ }^{\circledR}$, EZ Derm ${ }^{\circledR}$, and Mepilex ${ }^{\circledR}$. Using wound dressings like Mepitel $^{\circledR}$, N-Terface ${ }^{\circledR}$, Polyskin ${ }^{\circledR}$, and Biobrane ${ }^{\circledR}$ has no negative impact on keratinocytes. ${ }^{19}$ From our own experience, we can say that particular attention has to be paid to the applied antiseptic substance and to proper preparation of the donor site. Proper wound preparation for grafting is crucial - the high sensitivity of cultured cells to bacterial proteases and cytotoxins present in wound can impair the healing process and may result in a total loss of a cell transplant. This is another critical moment. ${ }^{20-23}$ That said, however, proper wound preparation is not sufficient - integrin profiles, as a result of a carried out culture, influence keratinocyte engraftment as well. When keratinocytes reach a high confluence, they evolve from a high proliferative state into stunted growth and differentiation. This is linked with integrin expression disturbances, such as the loss of expression of integrin alpha 1 and alpha $5 .{ }^{24}$ In the group of patients over 50 years of age, a moderately lower number of cells and a longer time necessary to obtain a clinically significant number of cells was reported.

All the above-mentioned obstacles lead to an increased cost of treatment and a prolonged hospital stay. This results in a lowered number of performed CEA transplantation procedures, even in reference centers. ${ }^{25}$ Pellegrini et al. suggested using stem cell transplants; however, in order to obtain a satisfying clinical result and to reduce the cost, a more careful selection of patients for a transplantation procedure is absolutely necessary. ${ }^{26}$ There is no doubt that the traditional predictive factors of mortality, like the burn surface and the patient's age, should be examined in detail. ${ }^{4}$ The results of the present study show that age has no influence on the survival rate of patients with a CEA transplant. This result is not surprising and is derived clearly from the evaluated data - the median age of a patient qualified for a cell culture was 41 years. Moreover, it has to be taken into consideration that the median age of all hospitalized patients was 45 years and a significant group of admissions included patients below 30 years of age (victims of communication accidents and flammable substance explosions). It is believed that the patient's age $>50$ years is a negative prognostic factor. ${ }^{27}$ The qualification of patients below 50 years of age for a cell culture is dictated not only by the median age of the admitted patients, but also by the skin aging process and the influence of this process on the normal morphology of cells, i.e., their ability to multiply. ${ }^{28,29}$ Patients with burns with $<20 \%$ TBSA affected are those most frequently admitted to burn centers; however, patients qualified for cell cultures are diagnosed with average burns of 40\% TBSA. Nevertheless, TBSA in the group of patients who underwent the epidermal cells therapy is not a predictive factor, but a larger surface area of $3^{\text {rd }} / 4^{\text {th }}$ degree burns increases the risk of death. In the group of patients with a cell transplant, this situation is clinically justified. Epidermal cells promote the healing process of burn wounds with a maximal depth of the $2^{\text {nd }}$ degree. Therefore, in the case of largescale burns, they can effectively support the wound healing process. Epidermal cells are unable to effectively stimulate the healing of deep ( $3^{\text {rd }}$ degree) wounds; thus, their application does not influence the survival in this group, and with a $20 \%$ increase of the $3^{\text {rd }}$ degree burn surface, the risk of death increases by 1.72 times. However, the mortality in the group of patients who underwent keratinocyte cell transplantation with a diagnosed burn of $<60 \%$ TBSA is $1 \%$, but in the case of $>60 \%$ TBSA affected, the reported mortality rate is at the level of $16 \%$. Tang et al. reported a zero mortality in the group of patients with burns of $<51 \%$ TBSA. It has been suggested that a unified system for surgical treatment procedures would cause the mortality rate decline in the group of burn patients. ${ }^{30}$ The influence of cell transplants on increased patient survival was not reported despite the fact that in the group of patients aged $<50$ years with keratinocytes applied, the mortality rate was only $4 \%$. Auxenfans et al. postulated using keratinocytes as a clinically effective method in managing donor sites and $2^{\text {nd }}$ degree burns with a large burn surface; in this case, together with a free split-thickness skin graft. ${ }^{31}$

In the case of extensive, deep burns ( $3^{\text {rd }}$ degree), the use of stem cells is recommended. ${ }^{32,33}$ At present, we can agree that the CEA transplant is a life-saving, but expensive procedure, unsuitable for the permanent coverage of burn wounds deeper than the $2^{\text {nd }}$ degree. ${ }^{34}$ Matters related to the optimal donor site selection for cell culture purposes, wound dressing applied to the wound before harvesting the donor skin for the culture and post-cell transplantation, and, most importantly, an informed choice of the group of patients for whom applying keratinocytes will give a maximum clinical effect, should have all been systematized many years ago. The lack of studies giving clear guidelines for using cultured skin components is to blame. The aim of this study was to establish preliminary standards for patient enrollment for keratinocyte cultures. It should be the basis for further discussion on this topic. 
In conclusion, keratinocytes and fibroblasts should be applied as an adjunctive method for the treatment of burns of at least $40 \%$ TBSA, but with a maximal depth of the $2^{\text {nd }}$ degree. In the group of patients below 50 years of age, a higher number of transplants with a cell population above 20 million/mL and a significantly lower mortality rate were observed, which means that in the mentioned age group, this graft is more effective. It has been suggested that patients older than 50 years of age with burns deeper than of the $2^{\text {nd }}$ degree should be treated with more advanced methods like, for example, the application of stem cells.

\section{References}

1. Atiyeh BS, Costagliola M. Cultured epithelial autograft (CEA) in burn treatment: Three decades later. Burns. 2007;33(4):405-413. doi: 10.1016/j.burns.2006.11.002

2. Sorg H, Betzler C, Rennekampff HO, Vogt PM. Burns [in German]. Unfallchirurg. 2012;115(7):635-648.

3. Atiyeh B, Masellis A, Conte C. Optimizing burn treatment in developing low- and middle-income countries with limited health care resources (Part 1). Ann Burns Fire Disasters. 2009;22(3):121-125.

4. Macedo JL, Santos JB. Predictive factors of mortality in burn patients. Rev Inst Med Trop Sao Paulo. 2007;49(6):365-370. doi: http://dx.doi. org/10.1590/S0036-46652007000600006

5. Shen $\mathrm{YM}, \mathrm{Hu} X \mathrm{XH}, \mathrm{Mi} \mathrm{HR}$, et al. Early treatment of high-voltage electric burn wound in the limbs [in Chinese]. Zhonghua Shao Shang Za Zhi. 2011;27(3):173-177. doi: 10.3760/cma.j.issn.1009-2587.2011.03.003

6. Kawecki M, Hoff-Lenczewska D, Klama-Baryła A, et al. Przeglad piśmiennictwa chirurgicznego. Warszawa, Poland: Fundacja Polski Przegląd Chirurgiczny; 2012:185-196.

7. Sood R, Balledux J, Koumanis DJ, et al. Coverage of large pediatric wounds with cultured epithelial autografts in congenital nevi and burns: Results and technique. J Burn Care Res. 2009;30(4):576586. doi: 10.1097/BCR.0b013e3181ac02de

8. Bargues $L$, Prat $M$, Leclerc $T$, et al. Present and future of cell therapy in burns. Pathol Biol (Paris). 2011;59(3):e49-56. doi: 10.1016/j.patbio.2009.12.006

9. Rab M, Koller R, Ruzicka M, et al. Should dermal scald burns in children be covered with autologous skin grafts or with allogeneic cultivated keratinocytes? - "The Viennese concept". Burns. 2005;31(5):578-586. doi: 10.1016/j.burns.2005.01.001

10. Carsin $\mathrm{H}$, Ainaud $\mathrm{P}$, Le Bever $\mathrm{H}$, et al. Cultured epithelial autografts in extensive burn coverage of severely traumatized patients: A fiveyear single-center experience with 30 patients. Burns. 2000;26(4): 379-387. doi: http://dx.doi.org/10.1016/S0305-4179(99)00143-6

11. Paddle-Ledinek JE, Cruickshank DG, Masterton JP. Skin replacement by cultured keratinocyte grafts: An Australian experience. Burns. 1997;23(3):204-211. doi: http://dx.doi.org/10.1016/S03054179(96)00123-4

12. Still JM, Orlet HK, Law EJ. Use of cultured epidermal autografts in the treatment of large burns. Burns. 1994;20(6):539-541. doi: http:// dx.doi.org/10.1016/0305-4179(94)90017-5

13. Desai MH, Mlakar JM, McCauley RL, et al. Lack of long-term durability of cultured keratinocyte burn-wound coverage: A case report. J Burn Care Rehabil. 1991;12(6):540-545. doi: 10.1097/00004630-19911100000009

14. Lataillade JJ, Bey E, Thepenier C, et al. Skin engineering for burns treatment [in French]. Bull Acad Nat/ Med. 2010;194(7):1339-1351.

15. Mühlbauer W, Henckel von Donnersmarck G, Hoefter E, Hartinger A. Keratinocyte culture and transplantation in burns [in German] Chirurg. 1995;66(4):271-276.
16. Braye F, Pascal P, Bertin-Maghit M, et al. Advantages of using a bank of allogenic keratinocytes for the rapid coverage of extensive and deep second-degree burns. Med Biol Eng Comput. 2000;38(2):248-252.

17. Sood R, Roggy D, Zieger M, et al. Cultured epithelial autografts for coverage of large burn wounds in eighty-eight patients: The Indiana University experience. J Burn Care Res. 2010;31(4):559-568. doi: 10.1097/BCR.0b013e3181e4ca29

18. Klama-Baryła A, Kraut M, Łabuś W, et al. Application of platelet leukocyte gel in in vitro cultured autologous keratinocite grafts. Pol Przegl Chir. 2011;2(22):77-86.

19. Esteban-Vives R, Young MT, Ziembicki J, et al. Effects of wound dressings on cultured primary keratinocytes. Burns. 2016;42(1):81-90. doi: 10.1016/j.burns.2015.06.016

20. Chester DL, Balderson DS, Papini RPG. A review of keratinocyte delivery to the wound bed. J Burn Care Rehabil. 2004;25(3):266-275.

21. Guilbaud J. Problems created by the use of cultured epithelia. Annals of the Mediterranean Burn Club. 1993;4(2):176-178.

22. Munster AM. Editorial: Whither skin replacement? Burns. 1997;23(2): 195. doi: http://dx.doi.org/10.1016/S0305-4179(97)86850-7

23. Ronfard V, Rives JM, Neveux $Y$, et al. Long-term regeneration of human epidermis on third degree burns transplanted with autologous cultured epithelium grown on a fibrin matrix. Transplantation. 2000;70(11):1588-1598. doi: 10.1097/00007890-200012150-00009

24. Poumay Y, Pittelkow MR. Cell density and culture factors regulate keratinocyte commitment to differentiation and expression of suprabasal K1/K10 keratins. J Invest Dermatol. 1995;104(2):271-276. doi: http://dx.doi.org/10.1111/1523-1747.ep12612810

25. Barret JP, Wolf SE, Desai MH, Herndon DN. Cost-efficacy of cultured epidermal autografts in massive pediatric burns. Ann Surg. 2000;231(6):869-876.

26. Pellegrini G, Ranno R, Stracuzzi G, et al. The control of epidermal stem cells (holoclones) in the treatment of massive full-thickness burns with autologous keratinocytes cultured on fibrin. Transplantation. 1999:68(6):868-879. doi: 10.1097/00007890-199909270-00021

27. Wolf SE, Rose JK, Desai MH. Mortality determinants in massive pediatric burns: An analysis of 103 children with > or $=80 \%$ TBSA burns (> or $=70 \%$ full-thickness). Ann Surg. 1997;225(5):554-565.

28. Gilchrest BA. In vitro assessment of keratinocyte aging. J Invest Dermatol. 1983;81(Suppl 1):184-189. doi: http://dx.doi.org/10.1111/15231747.ep12541084

29. Ito M, Liu Y, Yang Z, et al. Stem cells in the hair follicle bulge contribute to wound repair but not to homeostasis of the epidermis. Nat Med. 2005;11(12):1351-1354. doi: 10.1038/nm1328

30. Tang W, Li X, Deng Z, et al. Effects of unified surgical scheme for wounds on the treatment outcome of patients with extensive deep burn [in Chinese]. Zhonghua Shao Shang Za Zhi. 2015;31(4): 254-258. doi: 10.3760/cma.j.issn.1009-2587.2015.04.004

31. Auxenfans C, Menet V, Catherine Z, et al. Cultured autologous keratinocytes in the treatment of large and deep burns: A retrospective study over 15 years. Burns. 2015;41(1):71-79. doi: 10.1016/j. burns.2014.05.019

32. Mansilla E, Marín GH, Berges M, et al. Cadaveric bone marrow mesenchymal stem cells: First experience treating a patient with large severe burns. Burns Trauma. 2015;3(17):1-9. doi: 10.1186/s41038-0150018-4

33. Rasulov MF, Vasilchenkov AV, Onishchenko NA, et al. First experience of the use bone marrow mesenchymal stem cells for the treatment of a patient with deep skin burns. Bull Exp BiolMed. 2005;139(1):141-144. doi: 10.1007/s10517-005-0232-3

34. Mcheik JN, Barrault C, Levard G, et al. Epidermal healing in burns. Autologous keratinocyte transplantation as a standard procedure: Update and perspective. Plast Reconstr Surg Glob Open. 2014;2(9):e218. doi: $10.1097 /$ GOX.0000000000000176 